\title{
The Influence of Race on Employment Status and Earnings of African Immigrant Men in the United States
}

\author{
Yanyi K. Djamba ${ }^{1}$ and Sitawa R. Kimuna ${ }^{2}$ \\ ${ }^{1}$ Center for Demographic Research and Department of Sociology, Auburn University at Montgomery, P.O. Box 244023, Montgomery, \\ AL 36124-4023, USA \\ ${ }^{2}$ Department of Sociology, East Carolina University, A-416 Brewster Building, Tenth Street, Greenville, NC 27858-4353, USA
}

Correspondence should be addressed to Yanyi K. Djamba, ydjamba@aum.edu

Received 28 June 2011; Accepted 7 October 2011

Academic Editor: Abbas Bhuiya

Copyright ( 2011 Y. K. Djamba and S. R. Kimuna. This is an open access article distributed under the Creative Commons Attribution License, which permits unrestricted use, distribution, and reproduction in any medium, provided the original work is properly cited.

\begin{abstract}
This paper uses the labor queue theory to examine the changing influence of race on the employment status and earnings of African immigrant men in the United States between 1980 and 2008. The results show that the white advantage echoed in previous research has diminished. Black African immigrant men's chance of being employed is now greater than that of their white counterparts when their sociodemographic characteristics are taken into consideration. However, when human capital factors are included in the regression models, white African immigrant men still maintain a significant advantage in earnings. This study also uncovered differential impacts of marriage and school enrollment on white and black African immigrant men's employment and earnings. These results challenge the use of labor queue theory as a framework for explaining immigrants' experience in the US job market.
\end{abstract}

\section{Introduction}

Despite the increasing diversity of people living in the United States today, race remains a factor of interest and controversy among researchers and lay persons. This is probably more evident in the labor market where the person's race is said to affect their chance of employment and earnings. According to the labor queue theory, employers follow a preference ordering in selecting their workforce. In the United States, such preference is primarily based on race [1]. As Waldinger [2] put it, "In a race-conscious society like the United States, employers rank entire groups of people in terms of their ethnic and racial characteristics." Within the labor queue model, Whites are at the top of the queue, followed by Asians, Hispanics (Hispanics may be of any race [3]), and Blacks. Is the queuing explanation valid for African immigrant men? This study attempts to answer that question by examining differences in employment status and earnings between black and white African men.

The composition of the African immigrant male population in the United States has shifted from a white majority (56\%) to a black majority (72\%) during the period from 1980 to 2008. The change became apparent since 1990 as a result of a sustained economic growth in the United States (pull factor) and mounting economic and political crises in Africa (push factor). Further, it was sustained by the introduction in 1995 of the annual immigration program through which some 50,000 foreign-born people are admitted to the United States and granted permanent resident status.

What effect, if any, does such a changing racial composition have on African immigrant men's chance of employment and earnings in the United States? In this study, we use data from the US Census and American Community Survey to examine the influence of race on employment status and earnings of African immigrant men for the period of 1980-2008. Our key hypothesis is that the influence of race on African immigrant men's labor force participation and earnings may have changed or even diminished with shifting racial composition of the African immigrant population.

\section{Background and Rationale}

Immigration remains one of the issues that draw the most passionate and often divisive political debates in the United 
States [4]. Yet, many people are not aware that the United States has an immigration program that not only admits a predetermined number of foreign-born people every year to live and work in this country, but also increases the diversity of the immigrant population. This annual immigration program known as the Diversity Visa program (DV) was established by the US Congress in the early 1990s.

The DV program has been the major contributing factor of the increase in number of Africans in the United States. For example, 18,000 of the 105,915 African immigrants (19\%) who obtained legal permanent resident status in 2008 were DV recipients [5]. All African countries are eligible, but the number of applicants varies from country to country. For instance, according to the U.S. Department of State's immigration records, African countries with the most DV applicants in 2008 were Nigeria (684,735 entrants), Ethiopia (518,877 entrants), Egypt (291,220 entrants), Ghana (290,697 entrants), and Morocco (174,361 entrants) [6]. These same countries received the highest numbers of DV visas in 2008 (8,773 for Nigeria; 5,914 for Ghana; 5,241 for Ethiopia; 5,017 for Morocco, and 4,392 for Egypt) [7]. These top DV countries are also the major countries of origin for male African immigrants. For the period of 19802008, the majority of white male African immigrants came from Egypt, South Africa, and Morocco, whereas most black male African immigrants came from Nigeria, Ethiopia, and Ghana.

This increase in number of African immigrants has led to the insurgence of immigration studies in recent decades. Most studies based on the 1980-1990 census data revealed a significant racial effect on both employment opportunity and earnings. Analyzing the 1990 census data, Djamba [8] found that African immigrants' chance of employment in the United States depends greatly on their racial fitness. Whereas 84 percent of white African immigrant men aged 25 and older were employed, only 82 percent of black African immigrant men, 76 percent of black men from the Caribbean and South America, and 61 percent of African American men of the same age category were working in 1990. Even when their human capital factors were taken into account, white African immigrant men had a significant labor market participation advantage over black African immigrant men, black immigrant men from South America, and African American men.

This white African immigrants' advantage was also found in a study on socioeconomic patterns of Africans in the United States. Using the 1990 US census data, Kollehlon and Eule found that white African men and men from Englishspeaking Africa had higher net hourly earnings than their nonwhite and non-English-speaking counterparts [9]. How much has changed since then? Is the white advantage still relevant today?

Certainly, all new arrivals encounter difficulties in integrating into the new labor market, finding employment that is suitable to their professional qualifications, and attaining adequate economic returns $[10,11]$. These challenges are explained by restricted access to information [12], limited acquaintance with the host society, including language proficiency $[13,14]$, lack of personal contact [15], and racial bias.
But, as these new immigrants stay longer in their host country, the economic cost of immigration and some of the obstacles outlined above are expected to diminish.

Some studies have noted the variations among groups in terms of the economic cost of immigration [16]. Others have pointed to the country of origin as indicative of sociocultural resources and specific structural and ecological factors that may either hinder or enhance socioeconomic achievement in the host country [17]. Variations in economic outcomes among different foreign-born groups also derive from the treatment and sympathy the groups receive from the host country [18]. Further arguments have cited geographic areas into which the immigrants settle as playing an important role in affecting occupational and earning outcomes by exposing the immigrants to distinctive labor market conditions and opportunities [14].

This study extends previous research by examining the changing influence of race on the employment status and earnings of African immigrant men in the United States between 1980 and 2008. Due to gender segregation, nature of employment, and earnings, we focus only on men in this study and examine the situation of women in a separate article.

\section{Theoretical Perspectives and Research Hypotheses}

While the study of migration has become a major focus in social research, there have been only relatively few studies on African immigration to the United States.

Some studies that have examined African emigration have looked at the negative effects of such spatial mobility on countries of origin [19], the conditions that resulted in immigration to the US [20], and basic sociodemographic characteristics of black African-born populations in the US [21]. Other studies have attempted to explain the insertion of African immigrants in the American job market [8, 22-24].

Like other immigrants, African-born populations face challenges and opportunities when they arrive in the US. Their success or failure to adapt to the new environment depends on their premigration cultural legacies, the selectivity of migration, and prevailing job market practices at the place of destination [1]. We discuss these three perspectives below in order to construct a theoretical framework that helps us understand African immigrants' experiences in the American job market.

Under the premigration cultural legacies, the observed differences in labor force conditions and earnings are said to reflect each group's particular attitudes toward employment, schooling, family, kinship, and migration itself $[25,26]$. While the effects of some of the cultural legacy variables (e.g., education) can be statistically controlled, others such as social norms and values that denote family priorities are difficult to measure using secondary data.

The second explanation about the differences in labor force participation and earnings between African immigrants and other groups can be found in the selectivity of migration argument. The basic assumption is that people 
who migrate are usually among the most talented and ambitious [27]. As such, migrants are expected to have better labor market skills than nonmigrants [28].

The third type of explanation is based on the labor queue theory, which refers to the "amount of discrimination or favoritism particular groups encounter" [1]. According to this theory, employers are said to follow a preference ordering in selecting their workforce [29-31]. "In a race-conscious society like the United States, employers rank entire groups of people in terms of their ethnic and racial characteristics" [2]. Within the labor queue model, Whites are at the top of the queue, followed by Asians, Hispanics, and Blacks. Is the queuing explanation still valid today? Does it hold for African immigrant men?

This study focuses on the labor queue theory, according to which Whites are advantaged in the United States labor market. Therefore, we expect white African immigrant men to have higher labor force participation rate and higher earnings than black African immigrant men, net of their other sociodemographic characteristics.

\section{Data and Methods}

Two types of data are used in this study: (1) the decennial census data (1980, 1990, and 2000), and (2) the 2008 American Community Survey data. These data were drawn from the five percent Integrated Public Use Microdata Series (IPUMS). IPUMS is a collection of microdata, where each record is a person with all the characteristics numerically coded [32]. Using the IPUMS's data extraction system, we selected the variables needed for this research.

We use these data to show the trends and changing composition of the male population of African origin in the United States in the last three decades. Further analyses were conducted on the working age population to determine the importance of race through the labor queue theory, according to which white African immigrant men will have a better chance of employment and higher earnings than black African immigrant men.

\subsection{Definition of Variables}

4.1.1. Dependent Variables. There are two dependent variables: (1) labor force participation and (2) personal income. Labor force was measured by a dummy variable which indicates whether the person was working at the time of the data collection or not. To use the census definition, working is defined here as being at work or having a job but not presently at work. Personal income was measured by the respondent's annual income from the previous year in US dollars. The analyses of labor force participation and personal income are limited to individuals aged 16-64 years, which corresponds to the official working age in the United States.

4.1.2. Independent Variables. There are two sets of independent variables: (1) race, which divides the study population into three racial categories (Black, White, and other), and
(2) the sociodemographic variables, including the duration of immigration (the number of years immigrants have lived in the United States).

Race. The "Black" category is for persons born in Africa and who identified themselves as Black on the census or American Community Survey questionnaire. The "White" category includes all persons born in Africa and who identified themselves as White on the census or American Community Survey questionnaire. The third category, which includes all people whose races were not recorded either as Black or White, was classified as "other." The latter represents about five percent of male African immigrant population in the United States in 2008. Focusing on the labor queue theory, only the two main racial categories (Black and White) are analyzed in detail in this paper.

We recognize that the chances in the way the race variable has been measured in different censuses and American Community Survey may affect some outcomes. For example, the definition of race changed in 2000 with the introduction of individuals indicating two or more races. This may explain the increase in the "other race" category from less than 9 percent in the 1980 and 1990 to nearly 17 percent in 2000. Thus, to reduce the potential bias that may result from changes in racial categorization, we limit our analysis to individuals who self-identified themselves as black or white.

Sociodemographic Characteristics. Most work in the area of labor force participation follows the functionalist and human capital frameworks which suggest that family and individual resources determine skills, and skills increase the chance of occupational opportunity and earnings. This reasoning constitutes the benchmark of most current theories of labor force differences. In fact, many of the cultural and selectivity of migration assumptions are based on the influence of human capital variables on individuals' labor force participation and earnings. In light of the above theoretical framework and past studies on socio-economic conditions of immigrants [22, 23, 33-36], we identified several variables which are potential determinants of labor force participation and earnings.

We measured human capital through the following variables: age, education, and English language proficiency. Age and education/schooling are frequently cited as determinants of immigrants' labor market participation [14]. As noted above, we limited the analysis of labor force participation to persons aged 16-64 years.

Education was coded in years of schooling as follows: 08 years, 9-12 years, and 13 years and more. This educational classification is preferred to that of level of schooling (e.g., primary, secondary, and higher) because of differences in meaning across countries. We also included the school enrollment variable to control for the impact of the enrollment status on labor force participation and earnings. Although the IPUMS data do not include visa status information, the school enrollment variable can serve as a proxy to legal employment authorization if one assumes that many students - particularly foreign-born ones_-may not be allowed to work in the United States. English proficiency is an 
important variable of employment and overall integration into the American society. Chiswick [37] and Borjas [38] both argue that command of English can represent a large difference in earnings. This variable has the following categories: speaks only English: very good, good, not good.

Other important variables included in this study are sex and marital status. But due to sex differences in age of entry into labor force and other cultural meanings that may be associated with gender, we focus only on men in this study and will examine the women's situation in a separate study. Also of interest are duration of immigration and place of residence in the United States. Duration of immigration was constructed to test the assumption that immigrants tend to complete their integration/assimilation process within 1015 years [39]. Further, Chiswick [10] mentions that as time passes in the host country, immigrants acquire knowledge of customs and language relevant to jobs. This argument suggests that the longer an immigrant is in the United States, the greater the chances of participating in the labor force and earning a higher wage.

The residence variable was used to control for possible geographic effects which may increase or otherwise decrease the likelihood of entering into the labor force and of earning an income as a result of available local market opportunities. Following the classification used in previous research [40] and the U.S. Census Bureau's definition [41], four regions are defined in this study: northeast, midwest, south, and west. Given the higher percentage of native black population in the South, it is expected that the majority of black African immigrant men will reside in that region. But, because of historical racial discrimination, black African immigrant men's prospects for labor force participation and earnings may be lower in the south than elsewhere in the nation.

4.2. Analytical Procedures. Two types of analyses were performed: descriptive and multivariate. In the descriptive section, we examined the changes in the size and composition of the African immigrant male population, and their sociodemographic characteristics during the four periods considered in this study. The bivariate differences in labor force participation and average earnings were also analyzed. The multivariate section focused on the racial differences in labor force participation and earnings, controlling for the effects of the sociodemographic variables. More specifically, we estimated the probability of being in labor force using logistic regression models. Because personal earning was measured in dollars, we used multiple regression equations to determine the association between earning and sociodemographic variables of interest.

As noted earlier, the following questions are examined using the 5 percent IPUMS data from the last three censuses (1980, 1990, and 2000) and the 2008 American Community Survey: (1) Between black and white African men, which racial group has the best chance of employment and higher personal income in the United States? and (2) what effects, if any, do their social and human capital factors have on their chance of employment and personal income (earnings)?

\section{Results}

5.1. Changes in Size and Composition of Male African Immigrants. Data in Table 1 show that there were about 122,640 male African immigrants living in the United States in 1980. This number increased to 229,841 in $1990 ; 499,483$ in 2000 ; 787,931 in 2008. In terms of growth rate, the black male African immigrant population increased by an average annual growth of 43.5 percent between 1980 and 2008; the corresponding figures for white male African immigrants were 5.9 percent. The "other" racial group category increased by 9.9 percent during the same period. All together, the number of male African immigrants grew by 19.4 percent between 1980 and 2008 .

In addition, there have been significant changes in the composition of the male African immigrant population. For example, in 1980, the majority of male African immigrants were White $(56.5 \%)$, but since 2000 , Blacks have outnumbered Whites. By 2008, this racial makeup shifted to 71.8 percent Black, 23.3 percent White, and the remaining 5.0 percent for those male African immigrants whose racial identities were not specified (see Table 1).

5.2. Sociodemographic Characteristics of African Immigrant Men. Data in Table 2 show that, in all the four periods considered here, white African immigrant men were on average older than black African immigrant men. In addition, white African immigrant men had a longer duration of immigration to the United States as compared to their black counterparts. For example, whereas only about 4 in 10 black African immigrant men have lived in the United States for 10 years or more, the corresponding figure for white African immigrant men was 6 in 10 according to the 2008 American Community Survey data.

There were also important racial differences in the educational attainment, school enrollment, and marital status. Black African immigrant men had higher educational attainment than white African immigrant men in 1980 and 1990, but that situation was reversed in 2000 and 2008. For instance, in 2008, 76.6 percent of white African immigrant men had 13 or more years of formal education compared to 66.4 percent for black African immigrant men. In contrast, the percent of black African immigrant men with 13 or more years of formal education in 1980 was significantly higher $(82.1 \%)$ than that of white African immigrant men $(66.3 \%)$.

School enrollment rate has significantly decreased over time for both black and white African immigrants. Nonetheless, such enrollment remained relatively higher for black African immigrant men compared to white African immigrant men in all four periods. Such a racial difference in school enrollment suggests that many black African men may be coming to the United States as students or may decide to go to school once they are here in order to prepare themselves for better employment opportunities.

We also uncovered important differences in marital status between the two racial groups. On one hand, more than 60 percent of white African immigrant men were married at each of the four periods. On the other hand, only about half of black African immigrant men were married. Since 
TABLe 1: Distribution of the African immigrant male population (all ages) by race, 1980-2008.

\begin{tabular}{|c|c|c|c|c|c|c|c|c|}
\hline \multirow[b]{2}{*}{ Year } & \multicolumn{2}{|c|}{ Black } & \multicolumn{2}{|c|}{ White } & \multicolumn{2}{|c|}{ Other } & \multicolumn{2}{|c|}{ Total } \\
\hline & $N$ & $\%$ & $N$ & $\%$ & $N$ & $\%$ & $N$ & $\%$ \\
\hline 1980 & 42,940 & 35.0 & 69,340 & 56.5 & 10,360 & 8.4 & 122,640 & 100.0 \\
\hline 1990 & 117,393 & 51.1 & 97,551 & 42.4 & 14,897 & 6.5 & 229,841 & 100.0 \\
\hline 2000 & 288,019 & 57.7 & 129,179 & 25.9 & 82,285 & 16.5 & 499,483 & 100.0 \\
\hline 2008 & 565,421 & 71.8 & 183,473 & 23.3 & 39,037 & 5.0 & 787,931 & 100.0 \\
\hline $\begin{array}{l}\text { Annual growth rate } \\
\text { between } 1980 \text { and } 2008(\%)\end{array}$ & 43.46 & & 5.88 & & 9.89 & & 19.37 & \\
\hline
\end{tabular}

Source: compiled from IPUMS data sets.

Note: some percentages do not sum to 100.0 due to rounding.

TABle 2: Percentage distribution of Black and White African immigrant men aged 16 to 64 by selected sociodemographic characteristics.

\begin{tabular}{|c|c|c|c|c|c|c|c|c|}
\hline \multirow[b]{2}{*}{ Characteristics } & \multicolumn{2}{|c|}{1980} & \multicolumn{2}{|c|}{1990} & \multicolumn{2}{|c|}{2000} & \multicolumn{2}{|c|}{2008} \\
\hline & Black & White & Black & White & Black & White & Black & White \\
\hline \multicolumn{9}{|l|}{ Age group } \\
\hline 16 to 24 years & 22.4 & 24.8 & 11.6 & 14.0 & 15.2 & 10.6 & 16.4 & 9.2 \\
\hline 25 to 34 years & 55.7 & 30.2 & 45.3 & 34.5 & 27.4 & 23.8 & 25.1 & 19.9 \\
\hline 35 to 44 years & 17.3 & 23.4 & 33.2 & 27.7 & 35.3 & 32.4 & 26.4 & 29.6 \\
\hline 45 to 64 years & 4.6 & 21.6 & 9.9 & 23.8 & 22.2 & 33.2 & 32.1 & 41.3 \\
\hline \multicolumn{9}{|l|}{ Education } \\
\hline Less than 9 years & 1.5 & 4.4 & 2.7 & 2.2 & 3.6 & 1.7 & 4.2 & 1.4 \\
\hline 9 to 12 years & 16.4 & 29.4 & 17.3 & 19.7 & 31.5 & 23.3 & 29.4 & 22.0 \\
\hline 13 years or more & 82.1 & 66.3 & 80.0 & 78.2 & 64.9 & 75.0 & 66.4 & 76.6 \\
\hline \multicolumn{9}{|l|}{ Enrollment } \\
\hline Not in school & 38.2 & 73.2 & 61.1 & 80.6 & 72.5 & 84.9 & 73.2 & 87.7 \\
\hline In school & 61.8 & 26.8 & 38.9 & 19.4 & 27.5 & 15.1 & 26.8 & 12.3 \\
\hline \multicolumn{9}{|l|}{ Marital status } \\
\hline Not married & 51.8 & 39.3 & 49.1 & 37.7 & 46.6 & 34.5 & 48.4 & 32.3 \\
\hline Married & 48.2 & 60.7 & 50.9 & 62.3 & 53.4 & 65.5 & 51.6 & 67.7 \\
\hline \multicolumn{9}{|l|}{ Duration of immigration } \\
\hline Less than 5 years & 57.5 & 37.3 & 31.2 & 24.0 & 30.3 & 20.9 & 21.7 & 14.5 \\
\hline 5 to 9 years & 35.4 & 32.9 & 51.5 & 36.8 & 26.2 & 16.4 & 33.3 & 21.3 \\
\hline 10 years or more & 7.1 & 29.9 & 17.3 & 39.2 & 43.5 & 62.7 & 45.0 & 64.2 \\
\hline \multicolumn{9}{|l|}{ English proficiency } \\
\hline Speaks only English & 21.8 & 38.0 & 22.0 & 39.4 & 19.8 & 37.8 & 20.8 & 36.5 \\
\hline Speaks very well & 56.9 & 39.9 & 58.3 & 43.1 & 58.1 & 44.8 & 54.8 & 40.2 \\
\hline Speaks well & 19.4 & 19.1 & 16.2 & 14.7 & 17.5 & 14.0 & 19.0 & 17.8 \\
\hline Not well & 1.9 & 3.1 & 3.5 & 2.8 & 4.6 & 3.4 & 5.5 & 5.5 \\
\hline \multicolumn{9}{|l|}{ Region } \\
\hline Northeast & 34.7 & 31.7 & 27.3 & 34.4 & 28.7 & 29.6 & 24.0 & 30.5 \\
\hline Midwest & 19.4 & 14.0 & 14.0 & 10.9 & 17.1 & 12.6 & 18.7 & 13.3 \\
\hline South & 33.3 & 25.5 & 41.9 & 24.7 & 39.9 & 30.9 & 41.1 & 33.0 \\
\hline West & 12.7 & 28.8 & 16.8 & 29.9 & 14.3 & 26.9 & 16.2 & 23.2 \\
\hline \multicolumn{9}{|l|}{ Labor force participation } \\
\hline Not in labor force & 39.2 & 19.3 & 15.8 & 12.4 & 20.5 & 16.9 & 14.6 & 12.4 \\
\hline In labor force & 60.8 & 80.7 & 84.2 & 87.6 & 79.5 & 83.1 & 85.4 & 87.6 \\
\hline Average annual personal income & 7,423 & 16,278 & 17,785 & 35,657 & 28,202 & 57,474 & 33,290 & 72,789 \\
\hline Total number of cases & 39,620 & 53,940 & 10,6371 & 85,045 & 25,4334 & 10,9243 & 49,1038 & 15,6431 \\
\hline
\end{tabular}

Source: analysis based on 5 percent IPUMS data sets. 
married men tend to have more resources than unmarried ones $[42,43]$, this racial difference in marital status already suggests that white African immigrant men may have higher personal earnings than their black counterparts. Other data in Table 2 show interesting patterns across the four periods. For example, the percentage of African immigrant men who had a good command of the English language was high. More than 90 percent of both white and black African immigrant men said they spoke English well, very well, or as their native language (speaks only English).

The regional distribution of the African immigrant population changed over time. As hypothesized, the south has been the top region of residence for black African immigrant men. About 33 percent of all black immigrant men who were living in the United States in 1980 were in the south; the corresponding figure for white African immigrant men was 25.5 percent. The south has even become a preferred region for black African immigrant men in the subsequent periods. In contrast, Northeast was the region of choice for white African immigrant men in 1980 and 1990; 32 and 34 percent of them lived there, respectively, in 1980 and 1990. However, the South became the top region of residence also for white African immigrant men in 2000 and 2008.

What are the prospects of employment and earnings for black and white African immigrant men in the United States? The descriptive statistics in Table 2 show that although the majority of African immigrant men were in the labor force throughout the period considered here, there were some noticeable racial differences. In each of the four periods, the percent of labor force participants was higher for white African immigrant men than for their black counterparts. Nonetheless, the gap seems to be closing over time. For example, the percent of African immigrant men age 16-64 years who were in the labor force increased from 60.8 and 80.7 in 1980 to 85.4 and 87.6 in 2008, respectively, for Blacks and Whites.

However, white African immigrant men have a significant advantage over black African immigrant men when it comes to earnings. In all the four periods in Table 2, the average annual income of white African immigrant men is significantly higher than that of black African immigrant men. For example, a white African immigrant man earned an average annual income of $\$ 72,788.63$ (with a standard error of 260.44) in 2008, compared to $\$ 33,290.40$ (with a standard error of 56.53) for a black African immigrant man. How much of these differences account for differences in human capital factors? What role, if any, does race play?

\subsection{Determinants of Labor Force Participation among African} Immigrant Men. What chances do these populations have, especially the black African immigrant men in the US labor market? One study that examined the labor force participation of 25-64 years old African immigrant men in 1990 found significant racial differences, with black African men being more likely to be in labor force than white men [8]. What was the situation before that period? What is the situation today? Multivariate analysis of the labor force participation below answers those questions.
Two models are presented for each of the four years. Model I contains race, age, education, school enrollment, marital status, duration of immigration, English proficiency, and region of residence. Model II includes all the variables in Model I plus two interactions. The first interaction is for marriage and race; the second one is for school enrollment and race. The interaction terms were used to test the following two conditional hypotheses:

(1) since in most societies men are usually the breadwinners for their families and households, we expect married men to be more likely in the labor force than unmarried ones;

(2) school enrollment is expected to be a deterrent factor of labor force participation. Therefore, we expect men who are not in school to be more likely in labor force than their counterparts who are still in school.

The same interaction terms were also included in the regression equations of earnings to see if the observed racial differences in personal income are mediated by group differences in marriage and school enrollment.

Data in Table 3 show important changes in racial effect. In 1980, white African immigrant men were more likely to be in the labor force than black immigrant men, net of the effects of other covariates. However, this situation changed completely in the subsequent years. For example, black African immigrant men were significantly more likely to be in the labor force than their white counterparts in 2008. Therefore, the labor queue theory, which posits a White people advantage in the US labor force $[1,44]$ is confirmed only for the year 1980 .

The effects of all other variables were consistent throughout the period under study (1980-2008). For example, having higher educational attainment and being out of school significantly increase African immigrant men's chances of employment. In addition, age has a reversed U-shaped relationship with labor force participation. Similar to Djamba [8] study, our results show that marriage was associated with a higher chance of labor force participation for men. As mentioned earlier, men are usually the main providers for their families which explains the positive association between being married and having a job.

As for language, men with better command of the English language were more likely to be in the labor force than those with limited English language ability for the period of 19802000. However, in 2008, the influence of English language on employability significantly diminished; those with limited linguistic ability were more likely to be working than those who spoke English better. This change probably indicates increasing immigration of less skilled people who can take jobs that require little or no English language ability.

The coefficients for the duration of immigration show that immigrants who have been in the country for 5 years or more had a better chance of being in the labor force than the newcomers. The fact that those who lived in the United States for 5-9 years were also significantly more likely to be in labor force than newly arrived immigrants suggests that the work assimilation period for African immigrants is shorter 
TABLE 3: Odd ratios of logistic regression of labor force participation of black and white African immigrant men aged 16 to 64.

\begin{tabular}{|c|c|c|c|c|c|c|c|c|}
\hline \multirow[b]{2}{*}{ Characteristics } & \multicolumn{2}{|c|}{1980} & \multicolumn{2}{|c|}{1990} & \multicolumn{2}{|c|}{2000} & \multicolumn{2}{|c|}{2008} \\
\hline & Model I & Model II & Model I & Model II & Model I & Model II & Model I & Model II \\
\hline \multicolumn{9}{|l|}{ Race } \\
\hline White & 1.000 & 1.000 & 1.000 & 1.000 & 1.000 & 1.000 & 1.000 & 1.000 \\
\hline Black & $0.781^{* * *}$ & $0.660 * * *$ & $1.056^{* * *}$ & $0.929 * * *$ & $1.053^{* * *}$ & 0.993 & $1.285^{* * *}$ & $1.281^{* * *}$ \\
\hline \multicolumn{9}{|l|}{ Age group } \\
\hline 16 to 24 years & 1.000 & 1.000 & 1.000 & 1.000 & 1.000 & 1.000 & 1.000 & 1.000 \\
\hline 25 to 34 years & $1.600^{* * *}$ & $1.589^{* * *}$ & $1.987^{* * *}$ & $1.878^{* * *}$ & $1.675^{* * *}$ & $1.659^{* * *}$ & $3.680^{* * *}$ & $3.674^{* * *}$ \\
\hline 35 to 44 years & $2.115^{* * *}$ & $2.095^{* * *}$ & $2.231^{* * *}$ & $2.120^{* * *}$ & $1.646^{* * *}$ & $1.624^{* * *}$ & $3.773^{* * *}$ & $3.773^{* * *}$ \\
\hline 45 to 64 years & $1.481^{* * *}$ & $1.442^{* * *}$ & $1.321^{* * *}$ & $1.139^{* * *}$ & $1.375^{* * *}$ & $1.337^{* * *}$ & $2.082^{* * *}$ & $2.085^{* * *}$ \\
\hline \multicolumn{9}{|l|}{ Education } \\
\hline Less than 9 years & 1.000 & 1.000 & 1.000 & 1.000 & 1.000 & 1.000 & 1.000 & 1.000 \\
\hline 9 to 12 years & $1.895^{* * *}$ & $1.902^{* * *}$ & $1.578^{* * *}$ & $1.479^{* * *}$ & $1.514^{* * *}$ & $1.505^{* * *}$ & $2.313^{* * *}$ & $2.326^{* * *}$ \\
\hline 13 years or more & $2.642^{* * *}$ & $2.658^{* * *}$ & $3.075^{* * *}$ & $2.847^{* * *}$ & $3.050^{* * *}$ & $3.022^{* * *}$ & $3.902^{* * *}$ & $3.930^{* * *}$ \\
\hline \multicolumn{9}{|l|}{ Enrollment } \\
\hline Not in school & 1.000 & 1.000 & 1.000 & 1.000 & 1.000 & 1.000 & 1.000 & 1.000 \\
\hline In school & $0.140 * * *$ & $0.124^{* * *}$ & $0.199 * * *$ & $0.135^{* * *}$ & $0.446^{* * *}$ & $0.310^{* * *}$ & $0.301^{* * *}$ & $0.321^{* * *}$ \\
\hline \multicolumn{9}{|l|}{ Marital status } \\
\hline Not married & 1.000 & 1.000 & 1.000 & 1.000 & 1.000 & 1.000 & 1.000 & 1.000 \\
\hline Married & $1.820^{* * *}$ & $1.771^{* * *}$ & $1.531^{* * *}$ & $2.122^{* * *}$ & $1.432^{* * *}$ & $1.582^{* * *}$ & $1.598^{* * *}$ & $1.532^{* * *}$ \\
\hline \multicolumn{9}{|l|}{ Duration of immigration } \\
\hline Less than 5 years & 1.000 & 1.000 & 1.000 & 1.000 & 1.000 & 1.000 & 1.000 & 1.000 \\
\hline 5 to 9 years & $2.600 * * *$ & $2.616^{* * *}$ & $2.527 * * *$ & $2.600 * * *$ & $1.315^{* * *}$ & $1.324^{* * *}$ & $1.502^{* * *}$ & $1.502^{* * *}$ \\
\hline 10 years or more & $2.276^{* *}$ & $2.276^{* * *}$ & $1.920^{* * *}$ & $1.966^{* * *}$ & $1.358^{* * *}$ & $1.377^{* *}$ & $1.552 * * *$ & $1.550 * * *$ \\
\hline \multicolumn{9}{|l|}{ English proficiency } \\
\hline Speaks only English & $1.999^{* * *}$ & $1.999^{* * *}$ & $2.780^{* * *}$ & $2.877^{* * *}$ & $1.773^{* * *}$ & $1.764^{* * *}$ & $0.705^{* * *}$ & $0.706^{* * *}$ \\
\hline Speaks very well & $1.534^{* * *}$ & $1.537^{* * *}$ & $2.583^{* * *}$ & $2.659^{* * *}$ & $1.638^{* * *}$ & $1.630^{* * *}$ & $0.854^{* * *}$ & $0.855^{* * *}$ \\
\hline Speaks well & $1.316^{* * *}$ & $1.317^{* * *}$ & $2.090^{* * *}$ & $2.075^{* * *}$ & $1.274^{* * *}$ & $1.269^{* * *}$ & $0.866^{* * *}$ & $0.864^{* * *}$ \\
\hline Not well & 1.000 & 1.000 & 1.000 & 1.000 & 1.000 & 1.000 & 1.000 & 1.000 \\
\hline \multicolumn{9}{|l|}{ Region } \\
\hline Northeast & 0.981 & 0.984 & $0.889^{* * *}$ & $0.880^{* * *}$ & $0.854^{* * *}$ & $0.850^{* * *}$ & $1.100^{* * *}$ & $1.103^{* * *}$ \\
\hline Midwest & 1.021 & 1.025 & $0.931^{* *}$ & $0.917^{* * *}$ & 1.025 & 1.020 & $1.099^{* * *}$ & $1.103^{* * *}$ \\
\hline South & 1.000 & 1.000 & 1.000 & 1.000 & 1.000 & 1.000 & 1.000 & 1.000 \\
\hline West & $1.501^{* * *}$ & $1.504^{* * *}$ & $0.960^{*}$ & $0.940^{*}$ & $0.933^{* * *}$ & $0.927^{* * *}$ & $0.724^{* * *}$ & $0.728^{* * *}$ \\
\hline \multicolumn{9}{|l|}{ Interactions } \\
\hline Marriage by Race & & 1.037 & & $0.587^{* * *}$ & & $0.864^{* * *}$ & & $1.060^{* *}$ \\
\hline School Enrollment by Race & & $1.258^{* * *}$ & & $1.922^{* * *}$ & & $1.597 * * *$ & & $0.924^{* * *}$ \\
\hline-2 Log-Likelihood & 72,549 & 72,520 & 125,915 & 125,014 & 324,568 & 323,978 & 433,052 & 433,020 \\
\hline Total number of cases & 4,288 & 4,288 & 7,812 & 7,812 & 15,028 & 15,028 & 4,896 & 4,896 \\
\hline
\end{tabular}

*** $P \leq 0.001, \quad{ }^{* *} P \leq 0.01,{ }^{*} P \leq 0.05$.

Source: analysis based on 5 percent IPUMS data sets.

than the 10-15-year period echoed elsewhere [39]. We also found significant differences in labor force participation by region of residence. The northeast was not a good region of residence for African immigrant men in terms of labor force participation during the period of 1980-2000. During that period, African immigrant men who resided in the northeast had a lower chance of being in the labor force compared to those residing in the south. By 2008, the northeast became the top region of employability for African immigrant men.
Marriage and school enrollment can be race-specific conditions that increase or otherwise decrease the likelihood of being in the labor force. Therefore, we examined the interactions between race and marital status and race and school enrollment in Model II. The interaction between race and school enrollment in Table 3 shows that black immigrant men who were enrolled in school were significantly more likely to be in the labor force than those who were not in school, except in 2008 where they were less likely to do 
TABLE 4: OLS regression of annual personal income of black and white African immigrant men aged 16 to 64 (standardized coefficients).

\begin{tabular}{|c|c|c|c|c|c|c|c|c|}
\hline \multirow[b]{2}{*}{ Characteristics } & \multicolumn{2}{|c|}{1980} & \multicolumn{2}{|c|}{1990} & \multicolumn{2}{|c|}{2000} & \multicolumn{2}{|c|}{2008} \\
\hline & Model I & Model II & Model I & Model II & Model I & Model II & Model I & Model II \\
\hline \multicolumn{9}{|l|}{ Race } \\
\hline \multicolumn{9}{|l|}{ (White) } \\
\hline Black & $-0.154^{* * *}$ & $-0.108^{* * *}$ & $-0.172^{* * *}$ & $-0.127^{* * *}$ & -0.179 & $-0.106^{* * *}$ & $-0.186^{* * *}$ & $-0.112^{* * *}$ \\
\hline \multicolumn{9}{|l|}{ Age group } \\
\hline \multicolumn{9}{|l|}{16 to 24 years } \\
\hline 25 to 34 years & $0.046^{* * *}$ & $0.037^{* * *}$ & $0.098^{* * *}$ & $0.072^{* * *}$ & $0.057^{* * *}$ & $0.053^{* * *}$ & $0.051^{* * *}$ & $0.053^{* * *}$ \\
\hline 35 to 44 years & $0.222 * * *$ & $0.206^{* * *}$ & $0.204^{* * *}$ & $0.179^{* * *}$ & $0.132 * * *$ & $0.128^{* * *}$ & $0.109 * * *$ & $0.109 * * *$ \\
\hline 45 to 64 years & $0.272^{* * *}$ & $0.245^{* * *}$ & $0.279^{* * *}$ & $0.246^{* * *}$ & $0.175^{* * *}$ & $0.168^{* * *}$ & $0.127^{* * *}$ & $0.125^{* * *}$ \\
\hline \multicolumn{9}{|l|}{ Education } \\
\hline \multicolumn{9}{|l|}{ Less than 9 years } \\
\hline 9 to 12 years & $0.132 * * *$ & $0.134^{* * *}$ & $0.043^{* * *}$ & $0.032 * * *$ & $0.025^{* * *}$ & $0.024^{* * *}$ & $0.020^{* * *}$ & $0.014^{* * *}$ \\
\hline 13 years or more & $0.278^{* * *}$ & $0.281^{* * *}$ & $0.158^{* * *}$ & $0.146^{* * *}$ & $0.162 * * *$ & $0.161^{* * *}$ & $0.148^{* * *}$ & $0.139 * * *$ \\
\hline \multicolumn{9}{|l|}{ Enrollment } \\
\hline \multicolumn{9}{|l|}{ (Not in school) } \\
\hline In school & $-0.214^{* * *}$ & $-0.268^{* * *}$ & $-0.121^{* * *}$ & $-0.231^{* *}$ & $-0.079 * * *$ & $-0.178^{* * *}$ & $-0.093^{* * *}$ & $-0.233^{* * *}$ \\
\hline \multicolumn{9}{|l|}{ Marital status } \\
\hline \multicolumn{9}{|l|}{ (Not married) } \\
\hline Married & $0.091^{* *}$ & $0.174^{* * *}$ & $0.091^{* * *}$ & $0.183^{* * *}$ & $0.072 * * *$ & $0.192 * * *$ & $0.088^{* * *}$ & $0.225^{* * *}$ \\
\hline \multicolumn{9}{|l|}{$\begin{array}{l}\text { Duration of immigration } \\
\text { (Less than } 5 \text { years) }\end{array}$} \\
\hline 5 to 9 years & $-0.081^{* * *}$ & $-0.091^{* * *}$ & $-0.084^{* * *}$ & $-0.093^{* *}$ & $-0.072^{* *}$ & $-0.077^{* * *}$ & $-0.087^{* * *}$ & $-0.90 * * *$ \\
\hline 10 years or more & $-0.041^{* * *}$ & $-0.037^{*}$ & $-0.038^{* * *}$ & $-0.039 * * *$ & $-0.031^{* * *}$ & $-0.034^{* *}$ & $-0.059 * * *$ & $-0.63 * * *$ \\
\hline \multicolumn{9}{|l|}{ English proficiency } \\
\hline Speaks only English & $0.187^{* * *}$ & $0.186^{* * *}$ & $0.176^{* * *}$ & $0.184^{* * *}$ & $0.110^{* * *}$ & $0.109^{* * *}$ & $0.177^{* * *}$ & $0.174^{* * *}$ \\
\hline Speaks very well & $0.146^{* * *}$ & $0.149^{* * *}$ & $0.122^{* * *}$ & $0.132 * * *$ & $0.066^{* * *}$ & $0.067^{* * *}$ & $0.130^{* * *}$ & $0.128^{* * *}$ \\
\hline Speaks well & $0.043^{* * *}$ & $0.041^{* * *}$ & $0.039 * * *$ & $0.040^{* * *}$ & 0.001 & 0.000 & $0.040^{* * *}$ & $0.040^{* * *}$ \\
\hline \multicolumn{9}{|l|}{ (Not well) } \\
\hline \multicolumn{9}{|l|}{ Region } \\
\hline Northeast & $0.011^{* * *}$ & $0.013^{* * *}$ & $0.024^{* * *}$ & $0.022 * * *$ & $0.004^{* *}$ & 0.002 & $0.042^{* * *}$ & $0.038^{* * *}$ \\
\hline Midwest & $0.028^{* * *}$ & $0.031^{* * *}$ & $-0.005^{*}$ & $-0.007 * * *$ & $0.010^{* *}$ & $0.007^{* *}$ & 0.002 & $-0.002^{*}$ \\
\hline \multicolumn{9}{|l|}{ (South) } \\
\hline West & 0.001 & 0.002 & $0.031^{* *}$ & $0.028^{* * *}$ & $0.034^{* * *}$ & $0.032 * * *$ & $0.046^{* * *}$ & $0.040^{* * *}$ \\
\hline \multicolumn{9}{|l|}{ Interactions } \\
\hline Marriage by race & & $-0.141^{* *}$ & & $-0.147^{* * *}$ & & $-0.166^{* * *}$ & & $-0.176^{* * *}$ \\
\hline School enrollment by race & & $0.096^{* * *}$ & & $0.147^{* * *}$ & & $0.117^{* * *}$ & & $0.156^{* * *}$ \\
\hline R square & 0.367 & 0.377 & 0.244 & 0.259 & 0.177 & 0.188 & 0.186 & 0.197 \\
\hline Degree of freedom & 16 & 18 & 16 & 18 & 16 & 18 & 16 & 18 \\
\hline Total number of cases & 85,759 & 85,759 & 191,415 & 191,415 & 363,576 & 363,576 & 647,468 & 647,468 \\
\hline
\end{tabular}

Omitted categories in parentheses.

${ }^{* * *} P \leq 0.001,{ }^{* *} P \leq 0.01,{ }^{*} P \leq 0.05$.

Source: analysis based on 5 percent IPUMS data sets.

so. As for the interaction between race and marital status, the results are all positive but not consistently in the same direction. For example, being a married black man was associated with higher likelihood of being in the workforce in 1980 and 2008, but only the 2008 result was statistically significant. In 1990 and 2000, married black African immigrant men were significantly less likely to be in the labor force than other African immigrant men.
5.4. Group Differences in Earnings. Access to employment is only one of several factors of economic status. Data in Table 4 shows white African immigrant men earned more than black African immigrant men. For each of the four years considered in this study, black African immigrant men earned on average about half of what white African immigrant men earned (see Table 2). How much are the variations in earnings due to sociodemographic characteristics? 
Data in Table 4 show the results of the multivariate regression analysis of annual personal income presented as standardized coefficients. Findings indicate a persistent racial effect in the four periods. Considering the additive models (Model I), it appears that the labor queue hypothesis was confirmed because white African immigrant men earned more than their black counterparts, net of the effects of other variables. This result is consistent with earlier studies which noted a white advantage in earnings among African immigrant men $[9,45]$.

The rest of the variables were significantly associated with earnings during all the periods examined in this study. Education and age were positively and significantly associated with earnings. Clearly, education is a key positive factor of earnings. During all four periods examined here, more educated men earned substantially more than less educated ones. The positive association between age and earnings suggests that work experience translates into higher income.

Marriage was also associated with higher earnings for African immigrant men in general. However, when interaction between race and marital status was included in the regression equation, we found that the positive effect of marriage is mostly for white African immigrant men. For black African immigrant men, being married actually meant having lower personal earnings. This explains probably why black African immigrant men earn significantly more than white African immigrant men [46].

School enrollment was negatively associated with earnings in general. Yet, the analysis of the interaction effect between race and school enrollment showed that black African immigrant men who were in school earned higher income than their white counterparts with the same school enrollment status.

Unlike labor force participation, earning is negatively associated with the duration of immigration in the United States. Those who entered the country in recent years $(<5$ years) earned significantly more than earlier immigrants. In terms of language, the results in Table 4 show that men's linguistic skills were positively associated with earnings during all the four periods considered here.

The effect of region of residence shifted over time. In 1980, there was no significant difference in earnings between those African immigrant men who resided in the west and those in the south (reference category). In contrast, those immigrants who lived in the northeast and the midwest earned significantly more income than those in the south. In 1990, the northeast and the west residents earned significantly more, while the midwest residents earned significantly less than the south residents. In 2000, African immigrant men who lived in the south earned less than their counterparts who were living elsewhere in the country. The top earners during that year were those in the west followed by the midwest and then the northeast residents. The west region residents kept their earnings advantage even in 2008. During that year, the residents in the northeast earned significantly more than both the midwest and the south residents, but less than the west residents.

These results show that race remains a determinant factor of earnings for African immigrant men in the United
States. Even after controlling for the impact of human capital variables such as education, age, marital status, duration of immigration, English proficiency, and region of residence, white African immigrant men earned significantly more than black African immigrant men.

\section{Conclusion}

The study of race and migration is interesting as it offers an important way to look at the assimilation of foreign-born populations in the United States. This study highlights the changes in size and composition of the male African immigrant population in the United States during the periods of 1980-2008, and differences in the labor force participation and earnings between black and white African immigrant men aged 16-64 years. The results show that the number of male African immigrants in the United States continues to increase, and the racial composition is constantly changing.

How do these African immigrant men adapt into the US job market? This question was examined through the analysis of the labor force participation and earnings. The guiding framework was the labor queue theory, which asserts that Whites have a net advantage in the American job market. The results show significant racial differences, but not completely in line with the labor queue assumptions.

Throughout the four periods examined in this study, white African immigrant men were more likely to be in labor force than their black counterparts. However, in multivariate models, which controlled for the effects of other sociodemographic variables, the white advantage was only evident in 1980. Black African immigrant men had a net labor force participation advantage over their white counterparts in subsequent periods (1990-2008). What are the determinant factors of this change? It is possible that the increase in the number of African immigrants in the United States has given the employers chance to become more acquainted with black African immigrants, thus reducing some racial and ethnic prejudices. However, without specific information on employers' experiences with African immigrants, it is not possible to fully ascertain these changes in racial differences in labor force participation.

While black African immigrant men are apparently gaining more access to the US labor market than their white counterparts, their human capital characteristics have not yet translated into fair earnings. Black African immigrant men continue to earn significantly less than their white counterparts with the same sociodemographic characteristics. The labor queue assumption of a white advantage is therefore confirmed in the case of earnings differences between black and white African immigrant men.

Age, education, and English proficiency were positively and significantly associated with both the labor force participation and earnings. Such findings are consistent with previous research $[47,48]$ and reveal the importance of work experience, skills, and linguistic knowledge as key factors of assimilation. Nonetheless, we uncovered a negative association between labor force participation and English ability in 2008, suggesting less employment opportunities for im- 
migrants with higher skills at the onset of the economic recession.

As for marriage, this study showed that married men were more likely to be in the labor force and to earn higher income than unmarried ones, which is consistent with earlier results from socio-economic studies $[43,49]$. However, marriage has different mediating effects for white and black African immigrant men, when it comes to earnings. Marriage is associated with higher earnings for white African immigrant men, but lower earnings for black African immigrant men. This finding may explain the higher rate of dual-earning couples in black African immigrant families.

The analysis of the interaction between school enrollment and race showed that enrollment was associated with negative employment and earnings for white African immigrant men, whereas it had positive effects on both variables for black African immigrant men. The positive effect of the school enrollment and race interaction terms suggests that black African immigrant men who were in school probably had to work to pay their tuitions. On the other hand, white men who were in school may have had scholarships or other support systems that helped them devote more time to learning and less time to earning a living while in school.

Time in the United States was positively associated with the chance of employment and lower earnings. The effect of region of residence changed over time. Results reported here show that human capital characteristics are good predictors of the labor force participation and earnings, but other characteristics such as race and place of residence are still relevant though changing overtime. The labor queue hypothesis, which suggests that Whites are advantaged in the job market was only fully supported in this immigration study for earnings. As for labor force participation, the racial advantage has shifted from Whites to Blacks.

Certainly, other variables not examined in this study, such as other sources of income, and family size could shed more light on the racial differences in labor force participation and earnings uncovered here. Even in the absence of these unobserved factors, the results of this study suggest that the racial impact on the US job market has changed overtime as more people from diverse backgrounds work and live together. This could also be due to employers becoming more acquainted with various racial immigrant groups. More research is needed to understand these changes, especially the persistent white African immigrant men's earnings advantage over black African immigrant men. Another interesting question to explore in future research is whether race has the same impact on black and white African immigrants' labor force participation and earnings in Europe and elsewhere as in the United States.

\section{Acknowledgments}

This research was partially supported by a professional development grant from the Population Studies and Training Center at Brown University (USA) to the first author. The authors thank the anonymous reviewers for their helpful comments and suggestions. Thanks also are due to Sylvie Eke
Aba, a graduate research assistant, for helping with the construction of statistical tables, and Erin K. Brown, a program assistant, for preparing the list of references.

\section{References}

[1] S. Model, "An occupational tale of two cities: minorities in London and New York," Demography, vol. 34, no. 4, pp. 539550, 1997.

[2] R. Waldinger, Still the Promised City: African-Americans and New Immigrants in Postindustrial New York, Harvard University Press, Cambridge, Mass, USA, 1996.

[3] U.S. Census, Census Bureau, Washington, DC, USA, 2011, http://www.census.gov/prod/cen2010/briefs/c2010br-04.pdf.

[4] D. Merson, L. Kovacheff Badke, and J. C. Burkhardt, "Reframing the national conversation: immigration and higher education," The National Forum on Higher Education for the Public Good, Center for the Study of Higher and Post Secondary Education, University of Michigan, 2008.

[5] United States Department of Homeland Security, Yearbook of Immigration Statistics: 2008, U.S. Department of Homeland Security, Office of Immigration Statistics, Washington, DC, USA, 2009.

[6] United States Department of Homeland Security, "Total number of DV lottery applicants by country," 2011, http://www .travel.state.gov/pdf/TotalDVApplicantsbyCountry.pdf.

[7] United States, Department of State, "Total number of DV lottery applicants by country," 2011, http://travel.state.gov/visa/ immigrants/types/types_1317.html.

[8] Y. K. Djamba, "African migration to the United States: volumes, trends, and employment opportunities," The African Population in the 21st Century, vol. 2, pp. 471-480, 1999.

[9] K. T. Kollehlon and E. E. Eule, "The socioeconomic attainment patterns of Africans in the United States," International Migration Review, vol. 37, no. 4, pp. 1163-1190, 2003.

[10] B. R. Chiswick, "The effect of Americanization on the earnings of foreign Born men," Journal of Political Economy, vol. 86, no. 5, pp. 897-922, 1979.

[11] G. J. Borjas, "The earnings of male Hispanic immigrants in the United States," Industrial and Labor Relations Review, vol. 35, no. 3, pp. 343-353, 1982.

[12] B. Chiswick and T. A. Sullivan, "The new immigrants," in State of the Union: America in the 1990s, F. Reynolds, Ed., vol. 2, pp. 211-270, Russell Sage Foundation, New York, NY, USA, 1995.

[13] B. Chiswick and P. W. Miller, "English language fluency among immigrants in the United States," Research in Labor Economics, vol. 17, pp. 151-200, 1998.

[14] C. S. Greenlees and R. Saenz, "Determinants of employment of recently arrived Mexican immigrant wives," International Migration Review, vol. 33, no. 2, pp. 354-377, 1999.

[15] M. Granovetter, Getting a Job: A Study of Contacts and Careers, The University of Chicago Press, Chicago, Ill, USA, 2nd edition, 1995.

[16] A. Adsera and B. Chiswick, "Divergent patterns in immigrant earnings across European destinations," in Immigration and the Transformation of Europe, C. A. Parsons and T. M. Smeeding, Eds., pp. 85-110, Cambridge University Press, Cambridge, UK, 2006.

[17] K. Willis and B. Yeoh, "Introduction," in Gender and Migration, K. Willis and B. Yeoh, Eds., Cheltenham and Northampton, Edward Elgar, 2000.

[18] D. L. Poston Jr., "Patterns of economic attainment of foreignborn male workers in the United States," International Migration Review, vol. 28, no. 3, pp. 478-500, 1994. 
[19] United Nations Economic Commission for Africa (UNECA), Brain Drain: The Scope and Africa's Responses, International Organization for Migration, 2000.

[20] R. Worth and R. Asher, Africans in America, Facts on File, New York, NY, USA, 2004.

[21] J. R. Logan and G. Deane, Black Diversity in Metropolitan America. A Study Report, University of Albany, Lewis Mumford Center for Comparative Urban and Regional Research, 2003.

[22] F. N. A. Dodoo, "Earnings differences among blacks in America," Social Science Research, vol. 20, no. 2, pp. 93-108, 1991.

[23] F. N. A. Dodoo, "Assimilation differences among Africans in America," Social Forces, vol. 76, no. 2, pp. 527-546, 1997.

[24] Y. K. Djamba, "African immigrants in the United States: a socio-demographic profile in comparison to native blacks," Journal of Asian and African Studies, vol. 34, no. 2, pp. 210215, 1999.

[25] N. Foner, "The immigrant family: cultural legacies and cultural changes," International Migration Review, vol. 31, no. 4, pp. 961-974, 1997.

[26] T. Sowell, Race and Culture: A World View, Basic Books, New York, NY, USA, 1994.

[27] R. Kanbur and H. Rapoport, "Migration selectivity and the evolution of spatial inequality," Journal of Economic Geography, vol. 5, no. 1, pp. 43-57, 2005.

[28] B. Chiswick, "The economic progress of immigrants: some apparently universal patterns," in Contemporary Economic Problems, W. Fellner, Ed., pp. 357-399, The American Enterprise Institute, Washington, DC, 1979.

[29] T. O. Bisping and J. R. Fain, "The current state of the labor queue: national and regional evidence," Journal of Labor Research, vol. 26, no. 2, pp. 351-360, 2005.

[30] R. W. Hodge, "Toward a theory of racial differences in employment," Social Forces, vol. 52, no. 1, pp. 16-31, 1973.

[31] S. Lieberson, A Piece of the Pie: Black and White Immigrants Since 1880, University of California Press, Berkeley, Calif, USA, 1980.

[32] S. J. Ruggles, T. Alexander, K. Genadek, R. Goeken, M. Schroeder, and M. Sobek, Integrated Public Use Microdata Series: Version 5.0 [Machine-Readable Database], University of Minnesota, Minneapolis, Minn, USA, 2010.

[33] M. Tienda and A. Singer, "Wage mobility of undocumented workers in the United States," International Migration Review, vol. 29, no. 1, pp. 112-138, 1995.

[34] N. F. Dodoo, "Immigrant and native black workers' labor force participation in the United States," National Journal of Sociology, vol. 5, pp. 1-17, 1991.

[35] N. F. Dodoo, "Blacks and earnings in New York State," Sociological Spectrum, vol. 11, pp. 203-212, 1991.

[36] M. K. Corra and S. R. Kimuna, "Double jeopardy? Female African and Caribbean immigrants in the United States," Journal of Ethnic and Migration Studies, vol. 35, no. 6, pp. 1015-1035, 2009.

[37] B. R. Chiswick, "Speaking, reading, and earnings among low skilled immigrants," Journal of Labor Economics, vol. 4, no. 2, pp. 149-170, 1991.

[38] G. J. Borjas, "Assimilation changes in cohort quality, and the earnings of immigrants," Journal of Labor Economics, vol. 3, no. 4, pp. 462-489, 1985.

[39] M. Kalmijn, "The socioeconomic assimilation of Caribbean American blacks," Social Forces, vol. 74, no. 3, pp. 911-930, 1996.

[40] Y. K. Djamba and F. Bean, "Black and white African women in America: demographic profile and socioeconomic assimilation," African Population, vol. 14, no. 1, pp. 25-33, 1999.
[41] 2011, http://www.census.gov/geo/www/us_regdiv.pdf.

[42] A. J. Chiodo and M. T. Owyang, "For love or money: why married men make more," The Regional Economist, pp. 10-11, 2002.

[43] M. Pollmann-Schult, "Marriage and earnings: why do married men earn more than single men?" European Sociological Review, vol. 27, no. 2, pp. 147-163, 2009.

[44] R. M. Fernandez and M. L. Mors, "Competing for jobs: labor queues and gender sorting in the hiring process," Social Science Research, vol. 37, no. 4, pp. 1061-1080, 2008.

[45] F. N. A. Dodoo and B. K. Takyi, "Africans in the diaspora: black-white earnings differences among America's Africans," Ethnic and Racial Studies, vol. 25, no. 6, pp. 913-941, 2002.

[46] Y. K. Djamba and S. R. Kimuna, "The labor force participation and earnings gap among African immigrant women in the U.S.A.," Journal of International Migration and Integration. In press.

[47] D. Casale and D. Posel, "English language proficiency and earnings in a developing country: the case of South Africa," Journal of Socio-Economics, vol. 40, no. 4, pp. 385-393, 2011.

[48] A. Sum, I. Kirsch, and K. Yamamoto, Pathways to Labor Market Success: The Literacy Proficiency of U.S. Adult, Educational Testing Service, Princeton, NJ, USA, 2004.

[49] R. A. Nakosteen and M. A. Zimmer, "Spouse selection and earnings: evidence of marital sorting," Economic Inquiry, vol. 39, no. 2, pp. 201-213, 2001. 


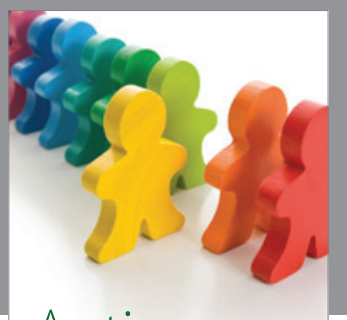

Autism

Research and Treatment
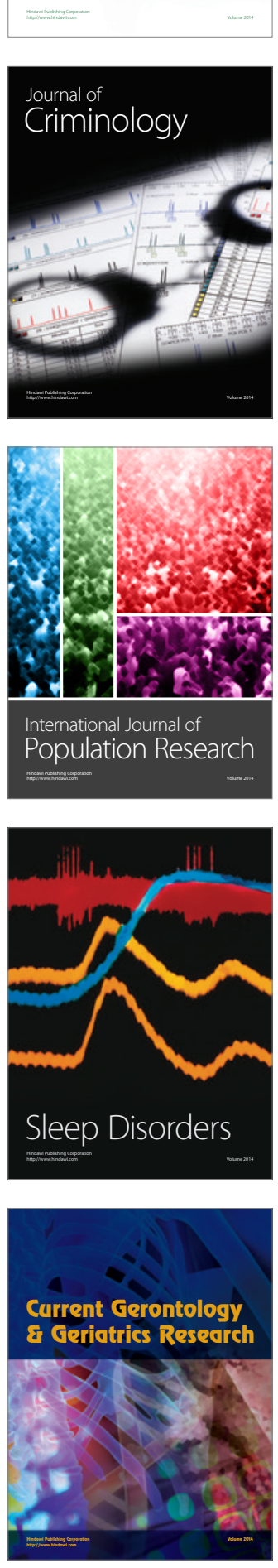
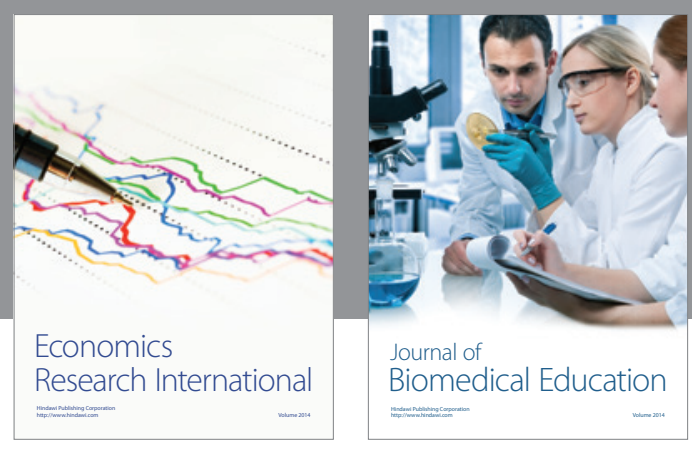

Journal of

Biomedical Education

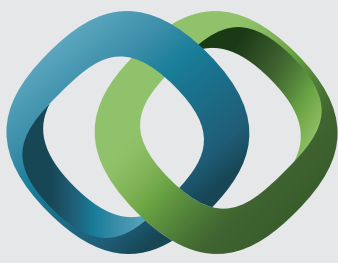

\section{Hindawi}

Submit your manuscripts at

http://www.hindawi.com
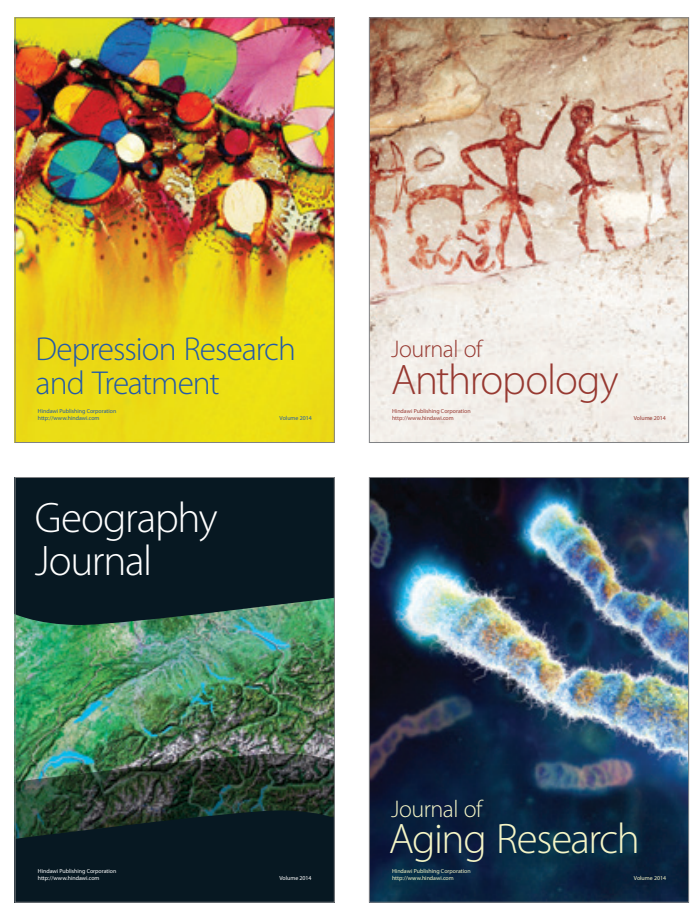

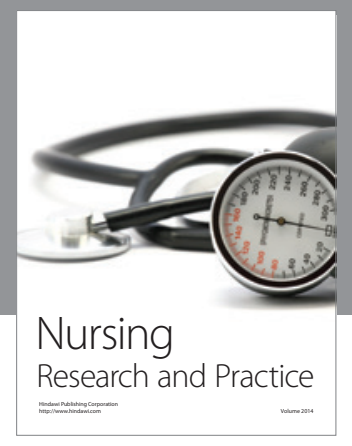

Nursing

Research and Practice

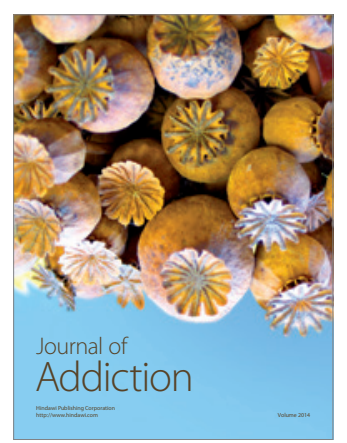

Child Development

Research

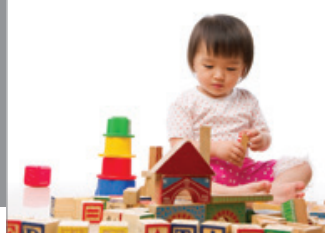

迥
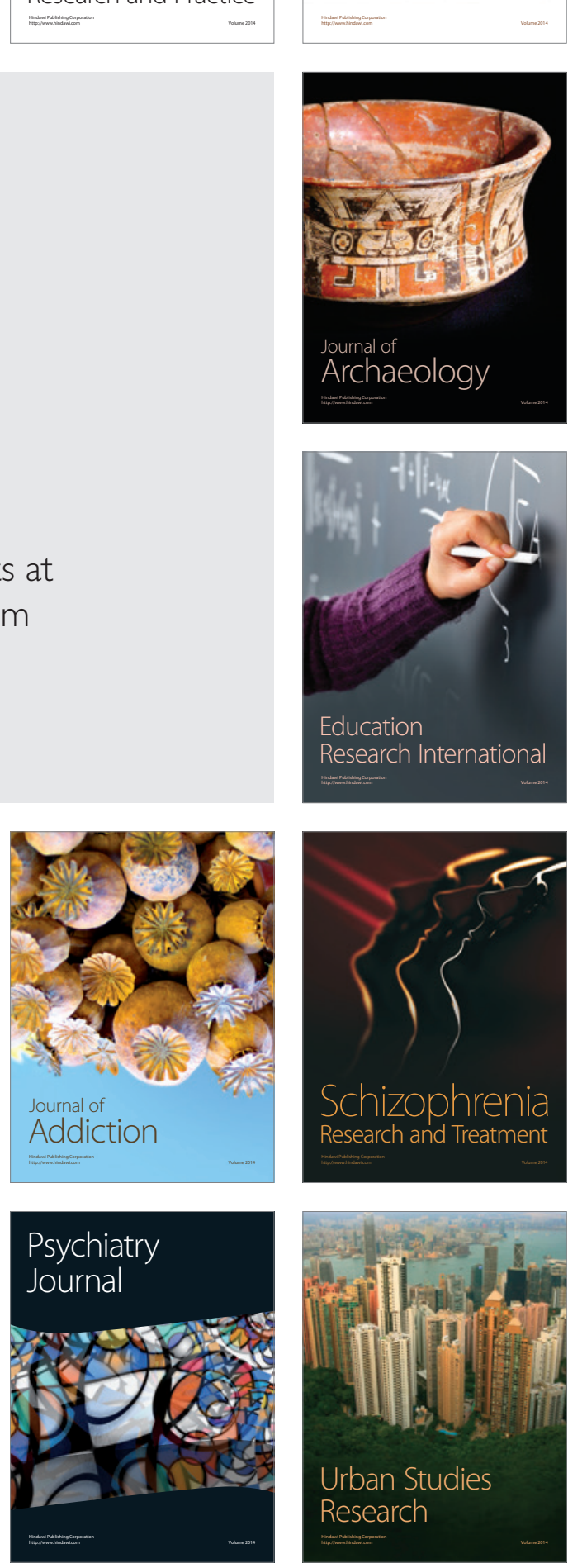